\title{
Improving Ballastless Track Quality Using Project Quality Management and SmartPLS
}

\author{
Putri Elsari Rahmayana ${ }^{1 *}$, Humiras Hardi Purba², and Budi Susetyo ${ }^{3}$ \\ ${ }^{1,3}$ Master of Civil Engineering Program, Mercu Buana University \\ Jln. Meruya Selatan No.1, Jakarta Barat 11650, Indonesia \\ ${ }^{2}$ Master of Industrial Engineering Program, Mercu Buana University \\ Jln. Meruya Selatan No.1, Jakarta Barat 11650, Indonesia \\ ${ }^{1}$ putrielsari94@gmail.com; ${ }^{2}$ humiras.hardi@mercubuana.ac.id; ${ }^{3}$ budi.susetyo@mercubuana.ac.id
}

Received: $9^{\text {th }}$ August 2020/ Revised: $8^{\text {th }}$ September 2020/ Accepted: $18^{\text {th }}$ September 2020

\begin{abstract}
How to Cite: Rahmayana, P. E., Purba, H. H., \& Susetyo, B. (2021). Improving Ballastless Track Quality Using Project Quality Management and SmartPLS. ComTech: Computer, Mathematics and Engineering Applications, 12(1), 19-32. https://doi.org/10.21512/comtech.v12i1.6616
\end{abstract}

\begin{abstract}
Transportation is still a significant problem in Indonesia. Indonesians prefer to use private vehicles for daily mobility purposes because public transportation lacks safety and comfort and has a longer trip duration. This issue causes congestion and air pollution problems. Hence, sustainable railbased public transportation is recommended. Light Rail Transit (LRT) tends to be congestion-free and has a relatively shorter travel time with a large passenger capacity. Most LRT track constructions use the ballastless track. However, this track construction is still new in Indonesia. The research aimed to determine the most important factors in improving ballastless track construction performance on LRT. The research referred to the existing LRT construction in Indonesia using Lean Construction (LC) and Project Quality Management (PQM) approaches. Statistical science approach with SmartPLS software was also used in data processing and modeling the relationship between variables. The research was conducted by distributing questionnaires to determine the most important factors in improving the quality of ballastless tracks with variables and indicators extracted from LC and PQM methods. From five tested hypotheses, only one hypothesis is accepted. Quality control has a positive effect on track quality. It is also found that quality control becomes the most important variable in improving ballastless track quality.
\end{abstract}

Keywords: ballastless track quality, Project Quality Management, Lean Construction, SmartPLS

\section{INTRODUCTION}

Transportation is still a major problem in Indonesia. Indonesians prefer to use private vehicles for daily mobility purposes because public transportation lacks safety and comfort and has a longer trip duration. This issue causes congestion and air pollution problems. Sianipar (2019) stated that total trips in Greater Jakarta (Jakarta, Bogor, Depok, Tangerang, and Bekasi) reached 47,5 million trips per day in 2015 . However, $50 \%$ of the trips were through traffic from Bogor, Depok, Tangerang, and Bekasi to Jakarta. Therefore, road performance was definitely low because the volume to capacity ratio was close to 1 .

Moreover, Bongso, Sendow, and Manoppo (2019) mentioned that the Volume Capacity Ratio (VCR) level on several roads in Manado City, such as Jalan Piere Tendean, with a VCR of 0,89 . It indicated a high traffic density using Level of Service (LOS). Both Sianipar (2019) and Bongso et al. (2019) recommended sustainable rail-based public transportation, namely Light Rail Transit (LRT). It tended to be congestionfree and had a relatively shorter travel time with a large passenger capacity.

Each train has its problems, such as the train getting off the railroad, the collapsed railroad, the train collision, and so on (Bakhrakh, 2014). At the very least, these problems result in physical and financial losses. Such problems can also cause immeasurable human losses. Based on train accident statistics from Statistics 
of Railway Accident (2020), train derailment ranks second after the railway crossing problem, which is the biggest cause of train accidents in Japan. Statistical data from Indian Railways also shows that most train accidents occur due to train derailments and crossing accidents (level crossing accidents). In contrast to Japan, India's train derailments are the largest cause of train transportation accidents (Dubbudu, 2016).

Some other accident examples include derailments in Switzerland, Colorado in the United States, and Russia. The general reason for all these problems is that the railway is not in a safe and right condition. Four common conditions can cause problems with the track: incorrect track geometry conditions, incorrect gauge connection, subgrade instability, and ballast instability (Bakhrakh, 2014). Based on data compiled from the Federal Railroad Administration (FRA), as a whole, the top two causes (rail damage and track geometry defects) account for $20 \%$ of derailment of freight trains on the mainline. It shows that prevention of these main causes can reduce a substantial risk of slipping (Liu, 2017). It is also confirmed that train track and equipment failure are a major cause of train derailment on straight lines, while money orders are the main cause of derailment in curved lanes or track changes (Liu, Saat, \& Barkan, 2012).

Then, Habtamu, Zhao, and Ren (2013) clustered LRT track construction into three major alternatives: ballasted track, prefabricated slab/floating ladder track, and green track. Among those three alternatives track, the green track was found the most suitable track construction for LRT systems. It was a ballastless track with the vegetation layer on top of the concrete surface.

Over the past 20 years, railroad technology has seen an increase in the use of concrete plate technology for transit, commuter, and high-speed rail (Tayabji \& Bilow, 2001). A ballastless track is a structural trajectory that the path with a particulate ballast is replaced by a cement base material (concrete or asphalt cement). With the spread of ballastless track technology, the field of concrete applications is expanded to the railroad. However, it is unfortunate that the phenomenon of cracking concrete in the path without ballast has emerged widely in highspeed railroad projects abroad and domestically (Xie, Li, Feng, \& Lee, 2009). Track without ballast or ballastless track is already at the forefront of railway engineering. It presents various advantages compared to conventional ballast track. This type of track is usually called "slab track" or "non-ballasted track" (Casal, 2010). Slab track or ballastless track structures (tracks using concrete plates) have been widely used in high-speed railways in Japan, Germany, France, and China. The ballastless slab track shows better stability and durability and has lower maintenance than the ballasted slab track system (Sun, Chen, \& Zelelew, 2013). If the track is above the ground, the subsoil must be homogeneous and withstand the imposed burden. Slab layers can be made as precast or in-situ concrete, using more efficient construction methods. The composition of concrete can further reduce construction costs (Smirnova, 2017).

According to Robertson et al. (2015) about ballastless track innovation called New Ballastless Track (NBT), from an economic perspective, it has a Return on Investment (ROI) of 10 to 20 years. When adding savings in civil works, some NBT projects will provide lower capital costs than ballasted track. Figure 1 shows an example of the ballastless track construction. A concrete arrangement of concrete sleepers replaces the ballast. There is also continuous concrete, such as a cast road. This type of construction can withstand greater axle loads than ballasted tracks. Hence, it is usually used for high-speed trains. However, there are some Mass Rapid Transit (MRT) or LRT that adopt this system as well.

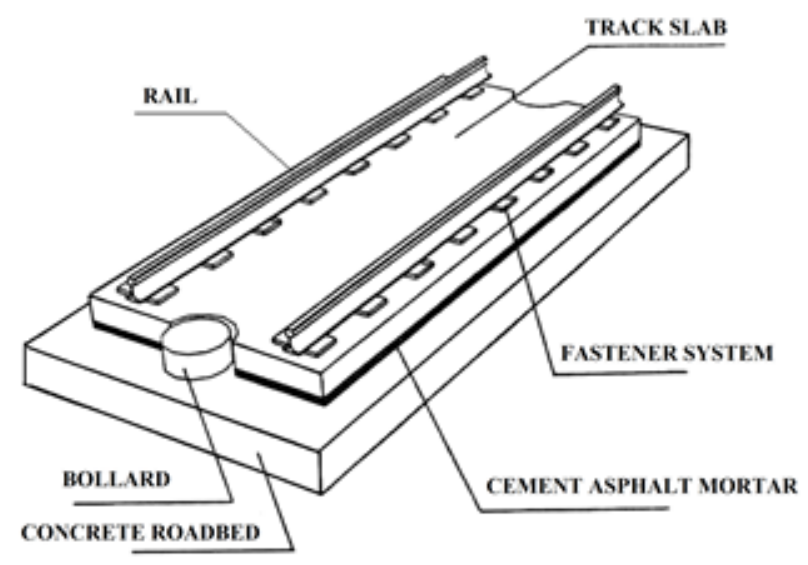

Figure 1 The Sketch of Ballastless Track System (Source: Yang, Kong, Cai, \& Wang, 2016)

The rails on the railway serve as a platform for rolling the train wheels and continuing the load from the train wheels to bearings with a standard of 25 meters. Rail is a significant component of rail transportation, and its integrity is essential to ensure railroad safety. Continuous Welded Rail (CWR) is generally used in ballastless tracks. These rails provide advantages of long service life, low maintenance, and better stability than ballast track (Wang, Liu, Wang, Liang, \& Ren, 2016).

Ballastless track uses concrete type bearings. There are two types of concrete bearings: double block concrete blocks (bi-block) and single block concrete (monolithic). Concrete bearings are heavy, which is between $160200 \mathrm{~kg}$. It has better rail stability for the forces at work and is more suitable for trains with large tonnage or high speeds (Fischer, Eller, Kada, \& Németh, 2015).

Moreover, there are two types of sleeper systems, namely embedded sleeper systems and non-embedded sleeper systems. The embedded sleeper system is the simplest track slab design. In this system, the ballast is only replaced by Concrete Support Layer (CSL). The bearings are used to adjust the track grid. After 
adjusting the geometry, they are cast together with a concrete slab (top/bottom approach). Meanwhile, the non-embedded sleeper system encloses the bearings in the elastomeric hull with an under sleeping pad (sleeping mat). The concrete is poured around, except for the BetonTragschicht mit Direktauflagerung (BTD) system. It uses a mono-block sleeper that is only placed on a concrete slab (Matias \& Ferreira, 2020).

Next, a fastening system is used to hold the rail element with the slab element. It must be an elastic type that has been proven well under service conditions on continuously welded tracks. The fastening system must have four anchor bolts on each rail seat. The distance between each binder is 0,65 $\mathrm{m}$, in straight and curved alignments. The estimated weight of the binder is $20 \mathrm{~kg}$ per binder system. Then, the maximum longitudinal limit per binder system is $13 \mathrm{kN}$. The goal is rail fasteners. Once installed, they will require minimum maintenance, and parts that fail can be easily replaced during the operating period. It is in accordance with the ability of elasticity that can be given by rail fastening (Karthiga, Selija, Javali, \& Elavenil, 2014).

A concrete slab replaces ballasts on the track slab without ballasts. The concrete track support layer and the monolithic concrete slab from the ballastless track system are made in-situ so that a concrete mixture with high workability is needed (Sun et al., 2013). The material and proportion of the determined and used mixture must maintain their integrity and be applicable to protect the corrosion of the embedded metal. The Reactive Powder Concrete (RPC) has better performance than Normal Concrete (NC). The tensile stress simulation is in the appropriate RPC strength capacity. Crack and arch damage in the slab, cement and asphalt mortars, and concrete roads are significantly reduced (Yang et al., 2016).

According to Casal (2010), there are the biggest advantages of ballastless tracks, especially highspeed trains. First, it is the significant reduction in the required maintenance over the life of the track. It leads to higher availability and a substantial reduction in costs around $20-30 \%$ compared to traditional ballasted track. Second, there is a significant improvement in track life. Third, there is no drag on the ballast by the high-speed train. Fourth, it has better control of the structural behavior in the tracks in terms of stiffness and stability. In addition, higher lateral resistance is achieved. Fifth, it has substantial weight and height reduction, making this type of solution more desirable on bridges or tunnels.

Pasquire (2012) emphasized that Lean Construction (LC) was an adaptation of Lean production and was based on a philosophy focusing on delivering better value. Moreover, Firoozi and Heravi (2013) suggested that the ultimate goal of LC was to provide value and eliminate or reduce waste. They stressed that the LC method might be implemented to improve the construction process and increase its efficiency.

The Lean approach focuses on continually increasing customer value by identifying and eliminating non-value-added activities that constitute waste. In service organizations, it exists as a methodology for reducing waste (in terms of time) and allowing processes to be more efficient. It requires checking the process from the client's perspective to eliminate waste and inefficiency (Antony, Snee, \& Hoerl, 2017). Waste can be defined as work activity that does not add value in transforming inputs into outputs along the value stream. The eliminated waste from the Lean approach is divided into two main categories, namely Type One Waste and Type Two Waste (Gaspersz \& Fontana, 2011). Meanwhile, waste variables are grouped into five categories, and the causes of waste are in six categories (Alwi, Mohamed, \& Hampson, 2002).

Moreover, the quality method is commonly used to evaluate the quality of railroads include Track Quality Index (TQI), Track Geometry Index (TGI), J Synthetic Coefficient, and European Norms (EN) 13848-5 (Berawi, Delgado, Calçada, \& Vale, 2010). Then, Track Recording Car (TRC) is combined with Track Geometry Index (TGI) and Deutsches Institut für Normung (DIN) EN 13848-5 by using available data from TRC to determine the geometry quality of the track and its deterioration. The track geometry deviation and irregularities are determined statistically using the TGI and DIN EN 13848-5. The result shows that a comparison between TGI and DIN serves as the basis to determine the stage of deterioration of each track and the effectiveness of interventions (Camacho, Le, Rapp, \& Martin, 2016). However, all these methods are only limited to quality assessment without any effort to improve quality.

Project Quality Management (PQM) consists of three processes: quality planning, quality assurance, and quality control. Quality planning guides quality activities in the future. It sets out the requirements and standards that must be met and the needed actions to fulfill them. Meanwhile, quality assurance carries out the planned quality activities and ensures that the project utilizes the needed processes to meet the quality standards and final goods requirements. Quality control ensures that quality assurance activities are carried out in accordance with the quality plan, and the requirements and standards are met (Nicholas \& Steyn, 2011).

The constraints faced by the project in the case study are the waste in the construction process, such as activities with no added value and the presence of defective product (slab track points), so that it requires reworking. Based on the mentioned description, the research aims to resolve these problems by applying the concept of quality control with the LC and PQM approach to identify and eliminate waste. The result is expected to improve the quality in the next project. 


\section{METHODS}

The research uses a case study. It takes the case on infrastructure projects, especially railroad. The object of the research is the Jakarta P102 Phase 1 LRT project on the grounds. The research investigates LRT railroad with a slab track system that is cast in-situ. At the time of the research, it is only available in this project.

The research uses a purposive sampling method. The researchers determine the sampling by determining specific characteristics following research objectives. Hence, it can answer the research problems by selecting personnel who are directly involved in the case study project. The respondents are stakeholders who are directly involved in the Jakarta LRT railway development project. The data collection is done by distributing questionnaires with offline and online surveys. About 40 questionnaires were distributed from 10 December 2019 to 19 December 2019. However, 31 questionnaires were returned with a response rate of $77,50 \%$.

Research variable is an attribute or nature or value of people, objects, or activities with certain variations determined by researchers to be studied. Then, conclusions can be drawn, which are divided into independent variables and dependent variables (Sugiyono, 2013). The independent variable (X) is from LC and PQM, and the dependent variable (Y) is the quality of the ballastless track. The variables and number of indicators can be seen in Table 1 .

Table 1 Research Variables and Indicators

\begin{tabular}{cllc}
\hline Code & Variables & Sub Variables & $\begin{array}{c}\text { Number of } \\
\text { Indicators }\end{array}$ \\
\hline X & LC and PQM & & \\
X.1 & & Lean (Waste) & 19 \\
X.2 & Quality Planning & 14 \\
X.3 & Quality Assurance & 10 \\
X.4 & Quality Control & 15 \\
X.5 & & Quality & 13 \\
& & Improvement & \\
Y & Ballastless Track & & 9 \\
& Quality & & \\
\hline
\end{tabular}

Hypotheses are temporary answers for problems that are still presumptive because they still need to be proven. The presumption answer is a temporary truth, which will be tested with the collected data through research. Testing the hypothesis will produce conclusions to reject or accept the hypothesis (Syafnidawaty, 2020). For the selection to be more detailed and easy, the researchers need an alternative hypothesis (Ha) and the null hypothesis (Ho). Ha is also called the working hypothesis or research hypothesis. Moreover, Ha is the opponent of Ho. Ha tends to be expressed in positive sentences, while Ho is expressed in negative sentences. Based on the variables, the research hypotheses are as follows.

H1 : Lean (LN) affects the ballastless track quality (TQ),

H2 : Quality planning (QP) affects the ballastless track quality (TQ),

H3 : Quality assurance (QA) affects the ballastless track quality (TQ),

H4 : Quality control (QC) affects the ballastless track quality (TQ),

H5 : Quality improvement (QI) affects the ballastless track quality (TQ).

Analysis of the research data uses a statistical approach in the form of reliability, frequency, validation test, and Smart Partial Least Square (SmartPLS) model. According to Haryono (2017), the purpose of PLS is to help researchers for predictive purposes. PLS is a Structural Equation Modeling (SEM) equation model based on components or variants. PLS-SEM focuses on explaining variances rather than covariances, making it a predictive-oriented approach to SEM (Shmueli, Ray, Estrada, \& Chatla, 2016). The formal model defines latent variables as the aggregate linear of the indicators. Weight estimates for creating the component score of latent variables are obtained based on how the inner model (the measurement model) and the relationship between indicators and constructs are specified. The result is the residual variance of the dependent variable.

The research is reflective because the latent variable indicator affects the indicator. For this reason, three methods of measurement are used, according to Haryono (2017). First, convergent validity measures the magnitude of the correlation between constructs and latent variables. Second, discriminant validity is carried out to ensure that each concept of each latent variable is different from the other variables. According to Haryono (2017), if the composite reliability value is $>0,7$ and Cronbach's alpha is above 0,60 , the construct is reliable. If the value is $\geq 1,96$ for t-statistics and $\leq$ 0,05 for $p$-values, the data are valid.

Third, inner models (inner relations, structural models, and substantive theory) describe the relationship between latent variables based on substantive theory. It is evaluated using R-squared for the dependent construct, Stone-Geisser Q-square test for predictive relevance, $t$-test, and the significance of the structural path parameter coefficients. Interpretation of $\mathrm{R}^{2}$ value is the same as $\mathrm{R}^{2}$ linear regression interpretation. It is the magnitude of the variability of endogenous variables that can be explained by exogenous variables. Table 2 shows the assessment criteria for the PLS-SEM model.

To achieve the research objectives and carry out the research systematically, a research flow diagram is needed. The flowchart of the research is illustrated in Figure 2. 
Table 2 Assessment Criteria for the Partial Least Square-Structural Equation Modeling (PLS-SEM) Model

\begin{tabular}{cll}
\hline No & \multicolumn{1}{c}{ Criteria } & \multicolumn{1}{c}{ Description } \\
\hline 1 & Loading Factor & $\begin{array}{l}\text { Loading factor value must be }>0,7 \text {. For research at the development } \\
\text { stage, a value of } 0,50-0,60 \text { is still acceptable. } \\
\text { Composite reliability measures internal consistency, and its value } \\
\text { must be }>0,7 .\end{array}$ \\
& AVE value must be $>0,5$. \\
3 & $\begin{array}{l}\text { Average Variance Extracted } \\
\text { (AVE) }\end{array}$ & $\begin{array}{l}\text { The square root value of AVE must be bigger than the correlation } \\
\text { value between latent variables. } \\
\text { Another measure of discriminant validity. It is expected that each } \\
\text { block indicator has a higher loading value for each measured latent } \\
\text { variable compared to the indicator for other latent variables. }\end{array}$ \\
\hline
\end{tabular}

(Source: Haryono, 2017)

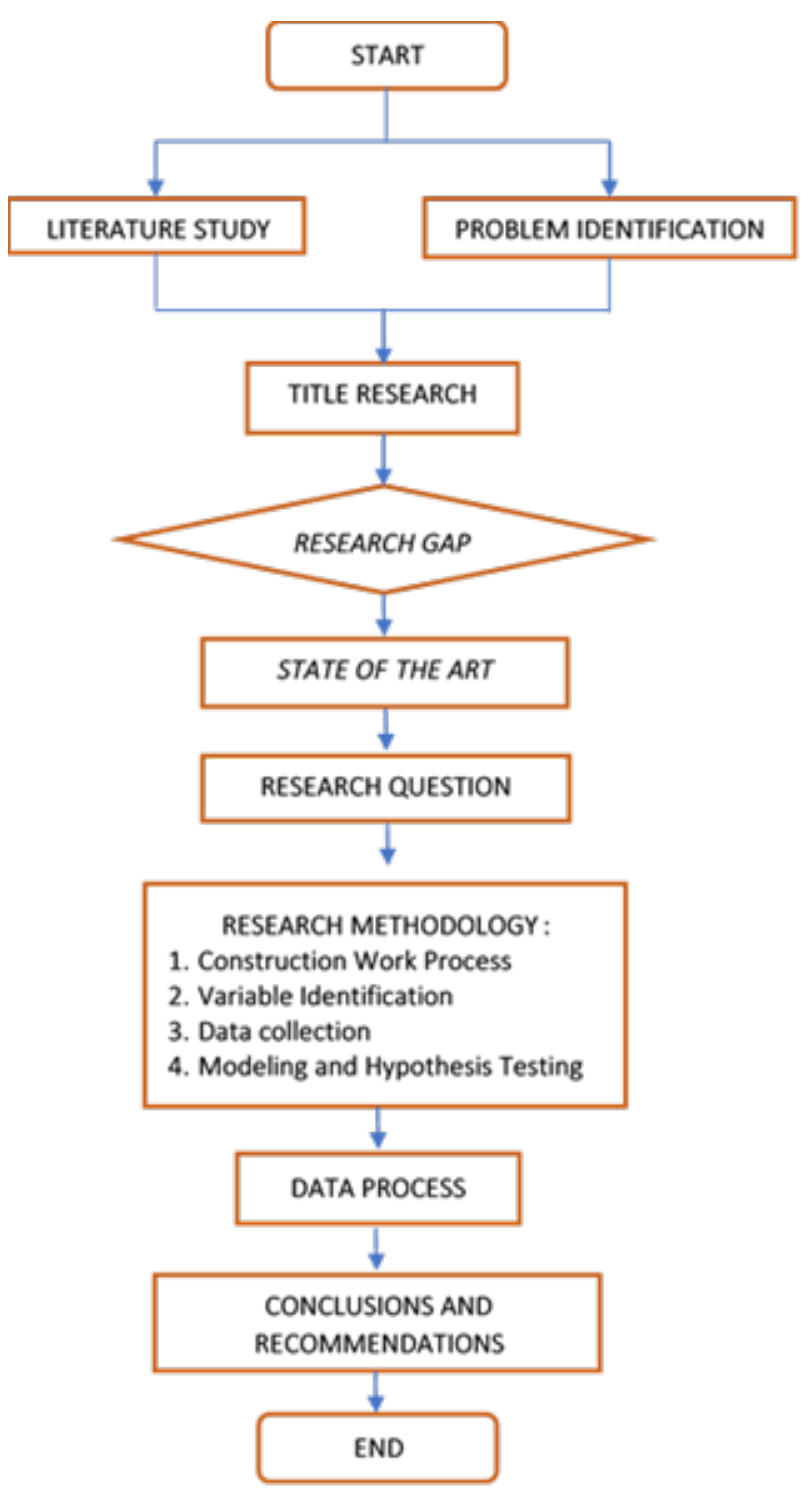

Figure 2 Research Flow Diagram 


\section{RESULTS AND DISCUSSIONS}

The relationship of variables and indicators using SmartPLS 3.2.8 is illustrated in Figure 3. It is the preliminary model before the process of elimination or modification of indicators. In preliminary model, there are 19 indicators for Lean, 14 indicators for quality planning, 10 indicators for quality assurance, 15 indicators for quality control, 13 indicators for quality improvement, and 9 indicators for ballastless track quality. The first step in using SmartPLS is testing the measurement model (outer model). The research analyzes convergent validity, discriminant validity, and composite reliability.

Convergent validity of the measurement model using reflective indicators is assessed based on the loading factor of the indicators that measure these variables. After the indicator of the output path coefficient diagram that has a loading factor coefficient below 0,6 is dropped, an analysis is performed again with the PLS software. Then, the indicator above 0,6 is generated in the third model analysis results, as shown in Figure 4. In the research, there are six variables with 80 indicators and a questionnaire scale of one to six. After the output path coefficient indicator, which has a loading factor coefficient below 0,6 , is dropped from the diagram of the next study, the researchers modify the model three times. Hence, the remaining indicator with a loading factor above 0,6 is shown in Table 3 (see Appendices).

Next, discriminant validity ensures that each concept of each latent variable is different from the other variables. The model has good discriminant validity if each loading value of a latent variable has the greatest loading value with another loading value of other latent variables. Table 4 (see Appendices) shows the value of cross loading and the existence of good discriminant validity. The correlation value of the indicator to the variable is higher than the correlation value of the indicator with other variables. For example, loading factor of LN.3 (indicator of Lean (waste)) is 0,901 which is higher than other loading factors: quality planning $(0,758)$, quality assurance $(0,737)$, quality control $(0,767)$, quality improvement $(0,690)$, and track quality $(0,693)$.

Then, variables are reliable if they have values above 0,70 for composite reliability, above 0,5 for AVE, and above 0,60 for Cronbach's alpha. The SmartPLS output in Table 5 shows that all variables have composite reliability values above 0,70 , AVE above 0,5, and Cronbach's alpha above 0,60. Therefore, it can be concluded that the variables have good reliability.

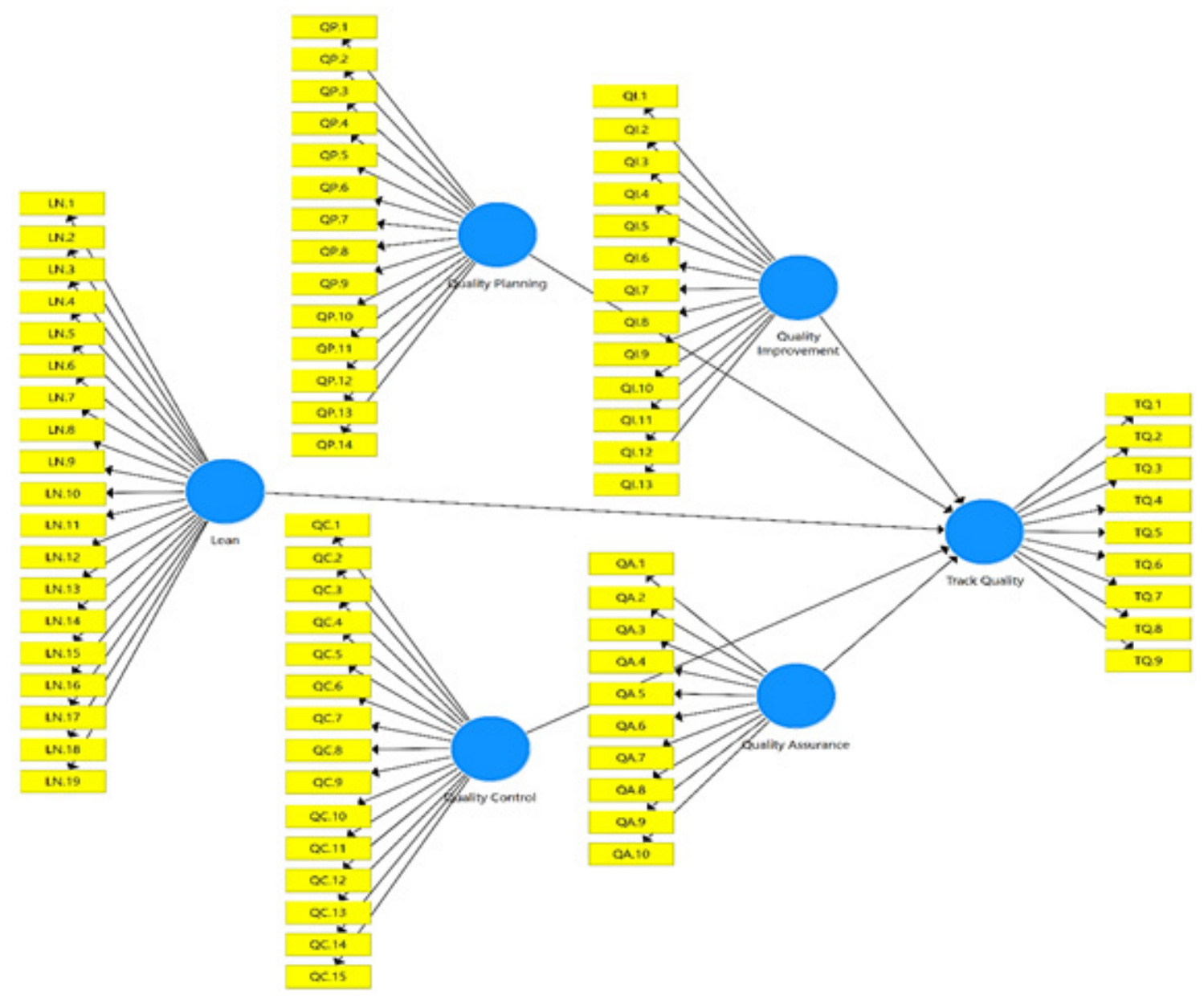

Figure 3 Preliminary Model

(Source: SmartPLS Results) 


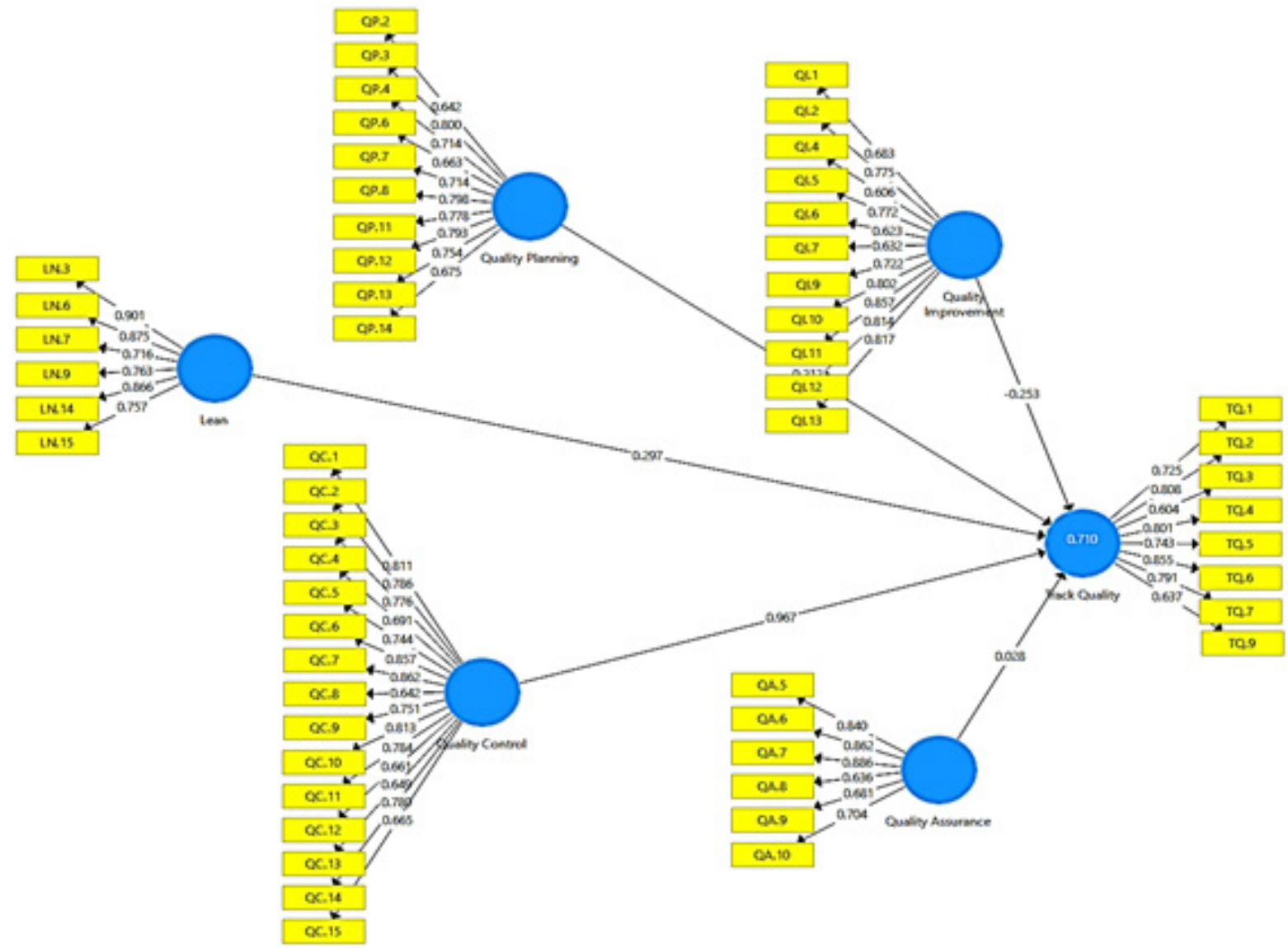

Figure 4 Output of Coefficient Fit (The Third Model)

(Source: SmartPLS Results)

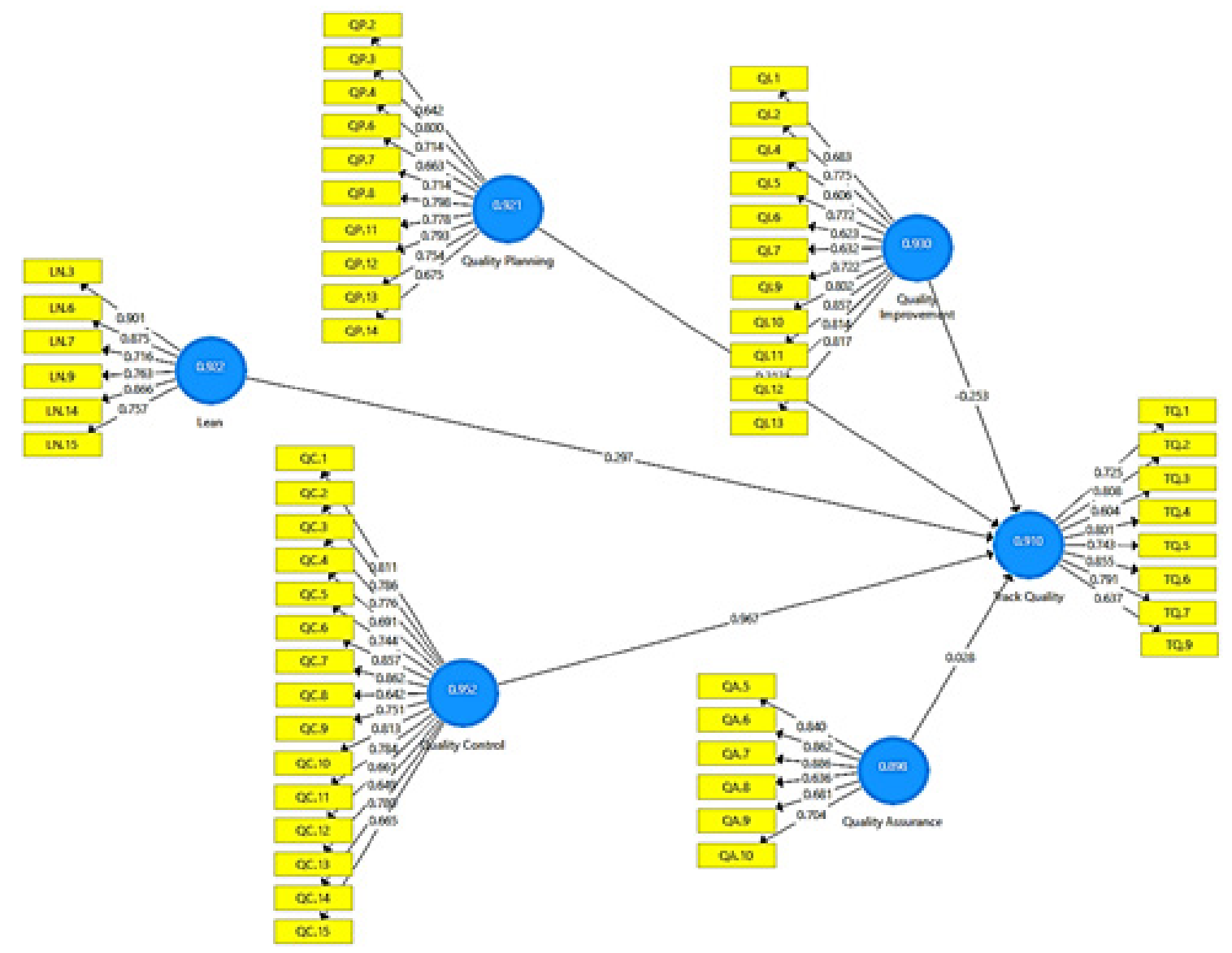

Figure 5 Final Model

(Source: SmartPLS Results) 
Table 5 Construct Reliability and Validity

\begin{tabular}{lcccc}
\hline Variables & $\begin{array}{c}\text { Cronbach's } \\
\text { Alpha }\end{array}$ & Rho_A & $\begin{array}{c}\text { Composite } \\
\text { Reliability }\end{array}$ & $\begin{array}{c}\text { Average Variance } \\
\text { Extracted (AVE) }\end{array}$ \\
\hline Lean (Waste) & 0,899 & 0,919 & 0,922 & 0,666 \\
Quality Planning & 0,905 & 0,911 & 0,921 & 0,541 \\
Quality Assurance & 0,862 & 0,881 & 0,898 & 0,599 \\
Quality Control & 0,945 & 0,952 & 0,952 & 0,570 \\
Quality Improvement & 0,917 & 0,926 & 0,930 & 0,550 \\
Track Quality & 0,887 & 0,896 & 0,910 & 0,563 \\
\hline
\end{tabular}

(Source: SmartPLS Results)

Table 6 Path Coefficients (Original Sample, Mean, Standard Deviation, T-Statistic, and P-Value)

\begin{tabular}{lccccc}
\hline Variables & $\begin{array}{c}\text { Original } \\
\text { Sample }(\mathbf{O})\end{array}$ & $\begin{array}{c}\text { Sample Mean } \\
(\mathbf{M})\end{array}$ & $\begin{array}{c}\text { Standard Deviation } \\
(\mathbf{S T D E V})\end{array}$ & $\begin{array}{c}\text { T Statistic } \\
(|\mathbf{O} / \mathbf{S T D E V}|)\end{array}$ & P-Value \\
\hline $\mathrm{LN} \rightarrow \mathrm{TQ}$ & 0,297 & 0,285 & 0,212 & 1,400 & 0,162 \\
$\mathrm{QP} \rightarrow \mathrm{TQ}$ & $-0,212$ & $-0,238$ & 0,320 & 0,663 & 0,508 \\
$\mathrm{QA} \rightarrow \mathrm{TQ}$ & 0,028 & 0,066 & 0,271 & 0,103 & 0,918 \\
$\mathrm{QC} \rightarrow$ TQ & 0,967 & 1,018 & 0,315 & 3,070 & 0,002 \\
$\mathrm{QI} \rightarrow \mathrm{TQ}$ & $-0,253$ & $-0,278$ & 0,273 & 0,929 & 0,353 \\
\hline
\end{tabular}

Note: $\mathrm{LN}=$ Lean, $\mathrm{QP}=$ Quality Planning, $\mathrm{QA}=$ Quality Assurance, $\mathrm{QC}=$ Quality Control, QI= Quality Improvement, and TQ= Track Quality.

(Source: SmartPLS Results)

Figure 5 is the final model that all indicators are valid and reliable. The model is stated valid as each loading factor value on the indicator (indicated by small arrows) is above 0,6 . Moreover, the model is also reliable as the composite reliability value (indicated by a blue circle on each variable) is already above 0,7 . In this final model, there are 6 remaining indicators for the Lean variable, 10 remaining indicators for quality planning, 6 remaining indicators for quality assurance, 11 remaining indicators for quality improvement, and 8 remaining indicators for track quality (ballastless track). Meanwhile, there is no eliminated indicator in quality control. It still consists of 15 indicators.

The second step in using SmartPLS is testing the structural model testing (inner model). The structural model in PLS is evaluated using $\mathrm{R}^{2}$ for the dependent variable. Meanwhile, the value of the path coefficient is for the independent variable, which is assessed for its significance based on the t-statistic value of each path. To assess the significance of the prediction model in structural models, the t-statistic value between the independent and dependent variables in the path coefficient table is used. It is from the SmartPLS output, as shown in Table 6. There are two types of relationship. First, it is positive relationship with track quality, such as Lean with original sample value of 0,297 , quality assurance with original sample value of 0,028 , and quality control with original sample value of 0,967 . Second, it is negative relationship with track quality. There are quality planning with an original sample value of $-0,212$ and quality improvement with an original sample value of $-0,253$.

The third step is hypotheses testing. The hypotheses are tested for correctness by looking at the significance level ( $p$-value). If the significance level from the calculation is below 0,05 , and the t-table is above 1,96 , the hypothesis is accepted. Vice versa, if the significant level is greater than 0,05 , and the t-table is below 1,96 , the hypothesis is rejected.

Table 6 shows the result of the hypothesis test. In H1, Ho1 means no effect of Lean on track quality, and Hal shows the effect of Lean on track quality. The effect of Lean (original sample) is 0,297. Meanwhile, $\mathrm{t}$-statistic of 1,400 is less than t-table of 1,96 . Then, the $p$-value is 0,162 . It is greater than 0,05 . The results accept Hol and reject Ha1. Thus, it means that Lean has no positive effect on track quality, or $\mathrm{H} 1$ is rejected. Lean does not have a significant effect on track quality. Hence, this variable is considered unimportant in improving the ballastless track quality.

In $\mathrm{H} 2$, the formulation is as follows. Quality planning has no effect on track quality (Ho2), and there is an effect of quality planning on track quality (Ha2). The results show the value of the original sample of $-0,212$. T-statistic of 0,663 is less than t-table of 1,96 , and p-value of 0,508 is greater than 0,05 . It means Ho 
is accepted, and Ha is rejected. Thus, quality planning has no positive effect on track quality. $\mathrm{H} 2$ is rejected. Quality planning does not have a major effect on track quality. This variable is also not important in improving the ballastless track quality.

In $\mathrm{H} 3$, it is formulated that there is no effect of quality assurance on track quality (Ho3), and there is an effect of quality assurance on track quality (Ha3). Path coefficient of quality assurance shows an original sample value of 0,028 . T-statistic of 0,103 is less than t-table of 1,96 . Then, $p$-value of 0,918 is greater than 0,05 . The results accept Ho and reject Ha. It implies that quality assurance has no positive effect on track quality. H3 is rejected. Hence, this variable is not important in improving the ballastless track quality.

In $\mathrm{H} 4, \mathrm{Ho} 4$ means no effect of quality control on track quality, and Ha4 shows an effect of quality control on track quality. The results have an original sample value of 0,967 . T-statistic of 3,070 is greater than the t-table of 1,96 . Then, $p$-value of 0,002 is less than 0,05 . Ho is rejected, and $\mathrm{Ha}$ is accepted. Quality control has a positive effect on track quality. H4 is accepted. Hence, quality control is important in improving the quality of ballastless track.

In H5, the formulation is as follows. There is no effect of quality improvement on track quality (Ho5), and there is an effect of quality improvement on track quality (Ha5). Path coefficient shows the quality improvement effect (original sample) of $-0,253$. T-statistic of 0,929 is less than t-table of 1,96 . Meanwhile, $p$-value is 0,353 . It is greater than 0,05 . The results accept Ho5 and reject Ha5. Quality improvement has no positive effect on track quality. H5 is rejected. Quality improvement does not have a major effect on track quality. Therefore, this variable is not important in improving ballastless track quality.

Based on the questionnaire survey results and SmartPLS, the essential variable in improving the quality of the ballastless track is quality control. It consists of 15 factors that can be used as a reference at the improvement stage. The indicators can be divided into three stages. First, it is monitoring (inspection) before carrying out the work. It consists of calibrating the measurement system (including the measuring instrument) that will be used in work, inspecting the specifications of incoming materials that will be used during the construction process, monitoring the process that has been improved and continue to improve it, and creating a measurement standard to maintain process performance.

Second, it is monitoring (inspection) during work execution (in the process). It consists of reviewing and inspecting each work progress, delivering the results of progress in the implementation of work, implementing every process control and work monitoring, identifying the most potential problems that may occur during the execution of the work, determining the strategy that will be used to maintain the improvement process, inspecting every activity that will be and is carried out so that it always meets the requirements, and identifying the specific actions and tools to support the objectives or improvements.

Last, it is monitoring (inspection) after the work is done. It consists of comparing the results of each work between the plan and its realization, defining a valid and reliable system, interpreting the difference between actual performance and planned performance, and conducting a final inspection of the work results.

\section{CONCLUSIONS}

Five variables are tested to find the most important factors in improving ballastless track quality. Based on the questionnaire results using SmartPLS, quality control positively affects the ballastless track quality. Hence, it is the most important factor in improving the ballastless track quality by referring to the 15 indicators in the variable. The indicator is divided into three parts of activities: monitoring before carrying out the work, monitoring during work execution (in the process), and monitoring after the work is done.

There are several limitations in the research. First, the research object is the ballastless track railway construction project that has been completed. However, there are no other similar ongoing projects, so the researchers cannot do the field validation. Second, combining the two quality methods of PQM and LC to improve the ballastless track quality is still relatively new for ballastless track construction. Therefore, for further research, it is highly recommended to implement the research results in a similar project that is currently running. The future researcher can also combine it with the Six Sigma method at the improvement stage. From this stage, it can investigate whether there is an improvement in quality by referring to the number of reduced defects so that quality can be improved continuously.

\section{REFERENCES}

Alwi, S., Mohamed, S., \& Hampson, K. (2002). Waste in the Indonesian construction projects. In Proceedings of the $1^{\text {st }}$ CIB-W107 International Conference-Creating a Sustainable Construction Industry in Developing Countries (pp. 305-315). CSIR.

Antony, J., Snee, R., \& Hoerl, R. (2017). Lean Six Sigma: Yesterday, today and tomorrow. International Journal of Quality \& Reliability Management, 34(7), 10731093. https://doi.org/10.1108/IJQRM-03-2016-0035

Bakhrakh, A. (2014). Solving problems of railway safety and maintenance with laser scanning systems. Retrieved from https:/www.spar3d.com/resources/ reports/solving-problems-of-railway-safety/

Berawi, A. R. B., Delgado, R., Calçada, R., \& Vale, C. (2010). Evaluating track geometrical quality through different methodologies. Journal of Technology, 1(1), 38-47.

Bongso, S. E., Sendow, T. K., \& Manoppo, M. R. (2019). Studi potensi jaringan Light Rail Transit (LRT) dan konstruksi perkerasan rel (Studi kasus: Koridor Kota 
Manado Kecamatan Malalayang, Kecamatan Sario, Kecamatan Wenang). Jurnal Sipil Statik, 7(10), 1317-1328.

Camacho, D., Le, T. H., Rapp, S., \& Martin, U. (2016). Light rail ballasted track geometry quality evaluation using track recording car data. Computers in Railways $X V$ : Railway Engineering Design and Operation, 162, 303-315. https://doi.org/10.2495/cr160281

Casal, H. B. (2010). Dynamic behaviour of highspeed railway bridges with ballastless track. Retrieved from https://fenix.tecnico.ulisboa. pt/downloadFile/395142048259/Dynamic\%20 behaviour $\% 20$ of $\% 20$ high-speed $\% 20$ railway $\% 20$ bridges $\% 20$ with $\% 20$ ballastless $\% 20$ track.pdf

Dubbudu, R. (2016). Accidents in Indian railways- Review of the last 6 years. Retrieved April 14 ${ }^{\text {th }} 2019$ from https://factly.in/indian-railway-accidents-statisticsreview-last-5-years/

Firoozi, M., \& Heravi, G. (2013). A Lean approach to industrialized and modular homebuilding: Identification and assessment of wastes in masshousing projects. In Proc. $4^{\text {th }}$ Construction Specialty Conf., Canadian Society for Civil Engineering (CSCE).

Fischer, S., Eller, B., Kada, Z., \& Németh, A. (2015). Railway construction. Universitas-Győr Nonprofit Kft.

Gaspersz, V., \& Fontana, A. (2011). Lean Six Sigma for Manufacturing and Service Industries. Vinchristo Publication.

Habtamu, A. L., Zhao, P., \& Ren, J. (2013). Track selection for Light Rail Transit (LRT) projects by applying Analytic Hierarchy Process (AHP) decision-making method-Case study: Evaluation of Addis Ababa Light Rail Transit (AALRT) project's track selection. In ICTE 2013: Safety, Speediness, Intelligence, LowCarbon, Innovation (pp. 634-649).

Haryono, S. (2017). Metode SEM untuk penelitian manajemen AMOS Lisrel PLS. Jakarta: Luxima Metro Media.

Karthiga, P., Selija, K., Javali, P. N., \& Elavenil, S. (2014). Analysis and design of ballastless track slab. International Journal of Emerging Technology and Advanced Engineering, 4(4), 69-76.

Liu, X. (2017). Statistical causal analysis of freighttrain derailments in the United States. Journal of Transportation Engineering, Part A: Systems, 143(2), 1-8. https://doi.org/10.1061/JTEPBS.0000014

Liu, X., Saat, M. R., \& Barkan, C. P. L. (2012). Analysis of causes of major train derailment and their effect on accident rates. Transportation Research Record, 2289(1), 154-163. https://doi.org/10.3141/2289-20

Matias, S. R., \& Ferreira, P. A. (2020). Railway slab track systems: Review and research potentials. Structure and Infrastructure Engineering, 16, 1635-1653. https://doi.org/10.1080/15732479.2020.1719167

Nicholas, J. M., \& Steyn, H. (2011). Project management for engineering, business and technology. Routledge.

Pasquire, C. (2012). Positioning Lean within an exploration of engineering construction. Construction Management and Economics, 30(8), 673-685.

Robertson, I., Masson, C., Sedran, T., Barresi, F., Caillau, J., Keseljevic, C., \& Vanzenberg, J. M. (2015). Advantages of a new ballastless trackform. Construction and Building Materials, 92, 16-22. https://doi.org/10.1016/j.conbuildmat.2014.06.099

Shmueli, G., Ray, S., Estrada, J. M. V., \& Chatla, S. B. (2016). The elephant in the room: Predictive performance of PLS models. Journal of Business Research, 69(10), 4552-4564.

Sianipar, A. (2019). Kajian preferensi masyarakat dalam menggunakan LRT Jabodebek. Jurnal Penelitian Transportasi Darat, 21(1), 13-20. https://doi. org/10.25104/jptd.v21i1.962

Smirnova, O. (2017). Concrete mixtures with highworkability for ballastless slab tracks. Journal of King Saud University - Engineering Sciences, 29(4), 381387. https://doi.org/10.1016/j.jksues.2017.06.004

Statistics of Railway Accident. (2020). Statistics of railway accident. Retrieved July $31^{\text {st }} 2020$ from http://www. mlit.go.jp/jtsb/statistics_rail.html

Sugiyono. (2013). Metode penelitian pendidikan: Pendekatan kuantitatif, kualitatif dan $R \& D$. Bandung: Penerbit Alfabeta.

Syafnidawaty. (2020). Hipotesis. Retrieved from https:// raharja.ac.id/2020/11/04/hipotesis/

Sun, L., Chen, L., \& Zelelew, H. H. (2013). Stress and deflection parametric study of high-speed railway CRTS-II ballastless track slab on elevated bridge foundations. Journal of Transportation Engineering, 139(12), 1224-1234. https://doi.org/10.1061/ (ASCE)TE.1943-5436.0000577

Tayabji, S. D., \& Bilow, D. (2001). Concrete slab track state of the practice. Transportation Research Record, 1742(1), 87-96. https://doi.org/10.3141/1742-11

Wang, K., Liu, C., Wang, D., Liang, J., \& Ren, T. (2016). Instrument for investigating the rail of a ballastless track under longitudinal temperature force. Advances in Mechanical Engineering, 8(7), 1-7. https://doi. org/10.1177/1687814016651816

Xie, Y., Li, H., Feng, Z., \& Lee, I. W. (2009). Concrete crack of ballastless track structure and its repair. International Journal of Railway, 2(1), 30-36.

Yang, J., Kong, B., Cai, C. S., \& Wang, J. S. (2016). Behavior of high-speed railway ballastless track slabs using reactive powder concrete materials. Journal of Transportation Engineering, 142(8), 1-18. https:// doi.org/10.1061/(asce)te.1943-5436.0000849 


\section{APPENDICES}

Table 3 Outer Loadings (Measurement Model)

\begin{tabular}{|c|c|c|c|}
\hline Variables & Preliminary Model & Model 2 & Model 3 (Final) \\
\hline \multicolumn{4}{|c|}{ Lean } \\
\hline LN.1<- LN & 0,404 & - & - \\
\hline $\mathrm{LN} .2<-\mathrm{LN}$ & 0,633 & 0,600 & - \\
\hline LN. $3<-$ LN & 0,875 & 0,894 & 0,901 \\
\hline LN. $4<-$ LN & 0,553 & - & - \\
\hline LN. $5<-$ LN & 0,314 & - & - \\
\hline LN. $6<-$ LN & 0,783 & 0,841 & 0,875 \\
\hline LN. $7<-$ LN & 0,696 & 0,735 & 0,716 \\
\hline LN. $8<-$ LN & 0,617 & 0,541 & - \\
\hline LN. $9<-$ LN & 0,703 & 0,735 & 0,763 \\
\hline LN.10<- LN & 0,449 & - & - \\
\hline LN.11<- LN & 0,582 & - & - \\
\hline LN. $12<-$ LN & 0,425 & - & - \\
\hline LN.13<- LN & 0,557 & - & - \\
\hline LN. $14<-$ LN & 0,856 & 0,883 & 0,866 \\
\hline LN. $15<-$ LN & 0,719 & 0,757 & 0,757 \\
\hline LN. $16<-$ LN & 0,314 & - & - \\
\hline LN. $17<-$ LN & 0,306 & - & - \\
\hline LN. $18<-$ LN & 0,552 & - & - \\
\hline LN. $19<-$ LN & 0,195 & - & - \\
\hline \multicolumn{4}{|c|}{ Quality Planning } \\
\hline QP.1<- QP & 0,514 & - & - \\
\hline $\mathrm{QP} .2<-\mathrm{QP}$ & 0,632 & 0,641 & 0,642 \\
\hline QP.3<- QP & 0,796 & 0,803 & 0,800 \\
\hline QP.4<- QP & 0,665 & 0,709 & 0,714 \\
\hline QP.5<- QP & 0,589 & - & - \\
\hline QP.6<- QP & 0,673 & 0.670 & 0,663 \\
\hline QP.7<- QP & 0,720 & 0,718 & 0,714 \\
\hline QP.8<- QP & 0,797 & 0,803 & 0,798 \\
\hline QP.9<- QP & 0,568 & - & - \\
\hline QP.10<- QP & 0,616 & 0,594 & - \\
\hline QP.11<- QP & 0,769 & 0,779 & 0,778 \\
\hline QP.12<- QP & 0,811 & 0,795 & 0,793 \\
\hline QP.13<- QP & 0,690 & 0,749 & 0,754 \\
\hline QP.14<- QP & 0,673 & 0,667 & 0,675 \\
\hline \multicolumn{4}{|c|}{ Quality Assurance } \\
\hline QA.1<- QA & 0,560 & - & - \\
\hline QA.2<- QA & 0,554 & - & - \\
\hline QA.3<- QA & 0,633 & 0,581 & - \\
\hline QA.4<- QA & 0,668 & 0,604 & - \\
\hline QA.5<- QA & 0,761 & 0,807 & 0,840 \\
\hline QA.6<- QA & 0,774 & 0,822 & 0,862 \\
\hline QA.7<- QA & 0,829 & 0,862 & 0,886 \\
\hline QA.8<- QA & 0,695 & 0,677 & 0,636 \\
\hline QA.9<- QA & 0,604 & 0,616 & 0,681 \\
\hline QA.10<- QA & 0,731 & 0,726 & 0,704 \\
\hline
\end{tabular}


Table 3 Outer Loadings (Measurement Model) (continued)

\begin{tabular}{|c|c|c|c|}
\hline Variables & Preliminary Model & Model 2 & Model 3 (Final) \\
\hline \multicolumn{4}{|c|}{ Quality Control } \\
\hline QC.1<- QC & 0,811 & 0,811 & 0,811 \\
\hline QC.2<- QC & 0,787 & 0,786 & 0,786 \\
\hline QC.3<- QC & 0,775 & 0,776 & 0,776 \\
\hline QC.4<- QC & 0,693 & 0,691 & 0,691 \\
\hline QC.5 <- QC & 0,745 & 0,744 & 0,744 \\
\hline QC.6<- QC & 0,857 & 0,857 & 0,857 \\
\hline QC.7<- QC & 0,862 & 0,862 & 0,862 \\
\hline QC.8 <- QC & 0,638 & 0,642 & 0,642 \\
\hline QC.9<- QC & 0,749 & 0,751 & 0,751 \\
\hline QC.10<- QC & 0,812 & 0,813 & 0,813 \\
\hline QC.11<- QC & 0,783 & 0,784 & 0,784 \\
\hline QC.12<- QC & 0,661 & 0,661 & 0,661 \\
\hline QC.13<- QC & 0,649 & 0,649 & 0,649 \\
\hline QC.14<- QC & 0,779 & 0,780 & 0,780 \\
\hline QC.15<- QC & 0,667 & 0,665 & 0,665 \\
\hline \multicolumn{4}{|c|}{ Quality Improvement } \\
\hline QI.1 <- QI & 0,682 & 0,686 & 0,683 \\
\hline QI.2<- QI & 0,776 & 0,777 & 0,775 \\
\hline QI.3 <- QI & 0,497 & - & - \\
\hline QI.4<- QI & 0,629 & 0,615 & 0,606 \\
\hline QI.5 <- QI & 0,785 & 0,773 & 0,772 \\
\hline QI.6<- QI & 0,628 & 0,623 & 0,623 \\
\hline QI.7 <- QI & 0,616 & 0,623 & 0,632 \\
\hline QI.8 <- QI & 0,610 & 0,592 & - \\
\hline QI.9 <- QI & 0,723 & 0,724 & 0,722 \\
\hline QI.10<- QI & 0,806 & 0,807 & 0,802 \\
\hline QI.11 <- QI & 0,833 & 0,848 & 0,857 \\
\hline QI.12<- QI & 0,792 & 0,804 & 0,814 \\
\hline QI.13<- QI & 0,808 & 0,822 & 0,817 \\
\hline \multicolumn{4}{|c|}{ Track Quality } \\
\hline TQ.1<- TQ & 0,720 & 0,725 & 0,725 \\
\hline TQ.2<- TQ & 0,793 & 0,808 & 0,808 \\
\hline TQ.3<- TQ & 0,607 & 0,693 & 0,604 \\
\hline TQ.4 <- TQ & 0,796 & 0,801 & 0,801 \\
\hline TQ.5 <- TQ & 0,745 & 0,745 & 0,743 \\
\hline TQ.6<- TQ & 0,857 & 0,856 & 0,855 \\
\hline TQ.7<- TQ & 0,788 & 0,791 & 0,791 \\
\hline TQ.8<- TQ & 0,504 & - & - \\
\hline TQ.9<- TQ & 0,646 & 0,637 & 0,637 \\
\hline
\end{tabular}

Note: LN= Lean, QP= Quality Planning, QA= Quality Assurance, QC= Quality Control, $\mathrm{QI}=$ Quality Improvement, and TQ= Track Quality.

(Source: SmartPLS Results) 
Table 4 Discriminant Validity Value (Cross Loading)

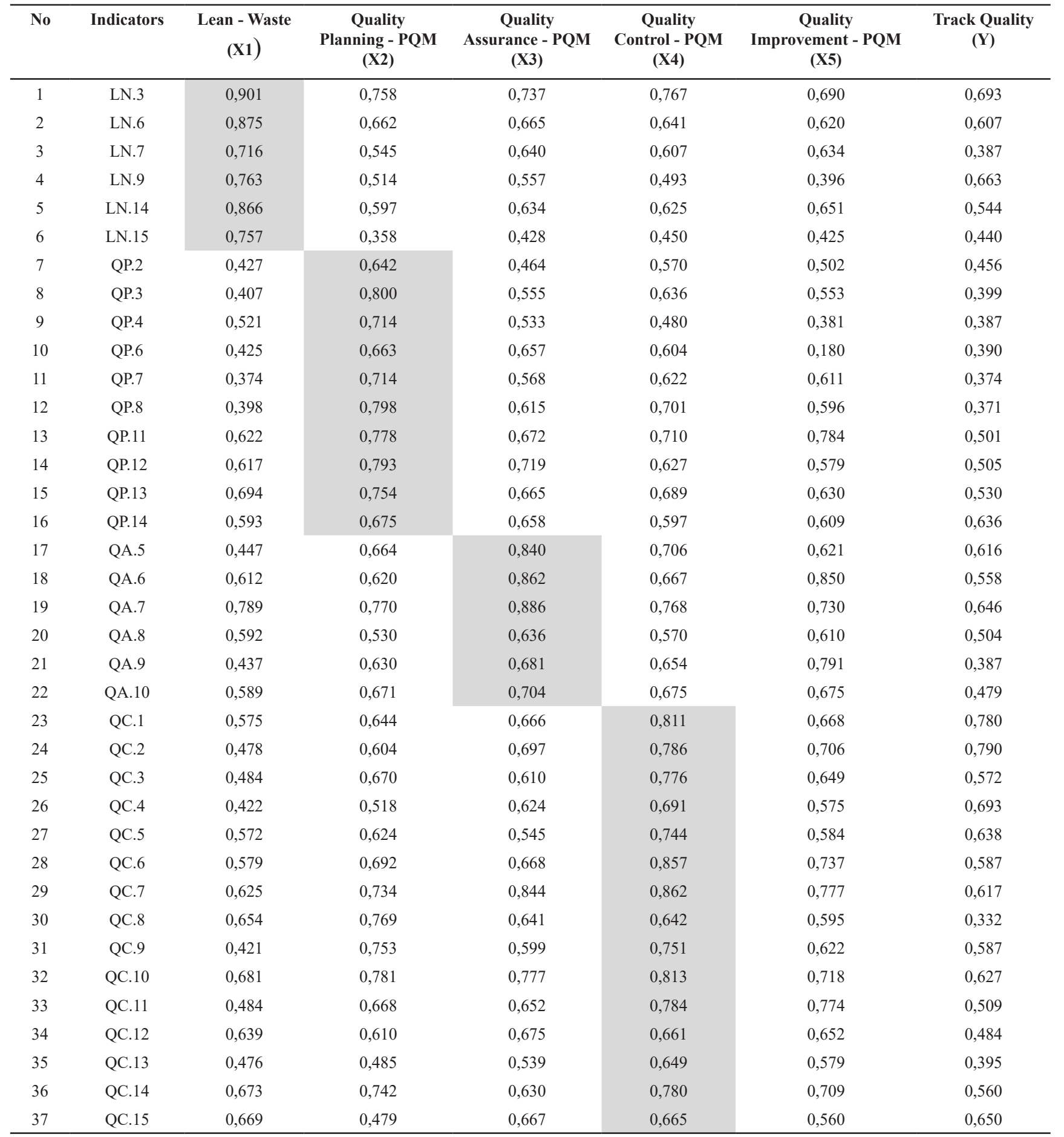


Table 4 Discriminant Validity Value (Cross Loading) (continued)

\begin{tabular}{|c|c|c|c|c|c|c|c|}
\hline No & Indicators & $\begin{array}{l}\text { Lean - Waste } \\
\text { (X1) }\end{array}$ & $\begin{array}{c}\text { Quality } \\
\text { Planning - PQM } \\
\text { (X2) }\end{array}$ & $\begin{array}{c}\text { Quality } \\
\text { Assurance - PQM } \\
\text { (X3) }\end{array}$ & $\begin{array}{c}\text { Quality } \\
\text { Control - PQM } \\
\text { (X4) }\end{array}$ & $\begin{array}{c}\text { Quality } \\
\text { Improvement - PQM } \\
\text { (X5) }\end{array}$ & $\begin{array}{c}\text { Track Quality } \\
\text { (Y) }\end{array}$ \\
\hline 38 & QI.1 & 0,345 & 0,560 & 0,541 & 0,652 & 0,683 & 0,384 \\
\hline 39 & QI.2 & 0,582 & 0,603 & 0,597 & 0,704 & 0,775 & 0,478 \\
\hline 40 & QI.4 & 0,595 & 0,412 & 0,447 & 0,447 & 0,606 & 0,258 \\
\hline 41 & QI.5 & 0,729 & 0,716 & 0,738 & 0,776 & 0,772 & 0,579 \\
\hline 42 & QI.6 & 0,489 & 0,686 & 0,504 & 0,563 & 0,623 & 0,316 \\
\hline 43 & QI.7 & 0,631 & 0,450 & 0,588 & 0,544 & 0,632 & 0,572 \\
\hline 44 & QI.9 & 0,449 & 0,744 & 0,684 & 0,747 & 0,722 & 0,497 \\
\hline 45 & QI.10 & 0,448 & 0,683 & 0,757 & 0,733 & 0,802 & 0,430 \\
\hline 46 & QI.11 & 0,484 & 0,665 & 0,639 & 0,634 & 0,857 & 0,524 \\
\hline 47 & QI.12 & 0,455 & 0,597 & 0,633 & 0,604 & 0,814 & 0,562 \\
\hline 48 & QI.13 & 0,434 & 0,565 & 0,705 & 0,660 & 0,817 & 0,478 \\
\hline 49 & TQ.1 & 0,518 & 0,451 & 0,460 & 0,609 & 0,469 & 0,725 \\
\hline 50 & TQ.2 & 0,517 & 0,527 & 0,546 & 0,678 & 0,521 & 0,808 \\
\hline 51 & TQ.3 & 0,530 & 0,421 & 0,455 & 0,577 & 0,441 & 0,604 \\
\hline 52 & TQ.4 & 0,607 & 0,555 & 0,690 & 0,788 & 0,644 & 0,801 \\
\hline 53 & TQ.5 & 0,508 & 0,516 & 0,485 & 0,446 & 0,334 & 0,743 \\
\hline 54 & TQ.6 & 0,543 & 0,537 & 0,601 & 0,609 & 0,516 & 0,855 \\
\hline 55 & TQ.7 & 0,478 & 0,441 & 0,457 & 0,556 & 0,446 & 0,791 \\
\hline 56 & TQ.9 & 0,483 & 0,364 & 0,408 & 0,455 & 0,410 & 0,637 \\
\hline
\end{tabular}

Note: LN= Lean, QP= Quality Planning, QA= Quality Assurance, QC= Quality Control, $\mathrm{QI}=$ Quality Improvement, and TQ= Track Quality.

(Source: SmartPLS Results) 